\title{
UNDERGROUND ELECTRICAL CONDUCTORS IN EUROPE AND AMERICA.
}

BY PROF. G. W. PLYMPTON.

The problems of construction of underground systems of electrical conduction will have been solved when the telephone and the arc light systems are both buried under our streets, without impairing the efficiency or durability of either.

By this I mean that all the difficulties encountered in burying conductors are involved in converting telephone and arc light from aerial to underground systems. Telegraph lines and systems of incandescent lighting present fewer difficulties in the process of burying, and none of a kind not met with in dealing with the systems first mentioned.

The telephone problem is substantially solved. Some details only remain to be settled, among which may be mentioned the best size of conductor, the most serviceable insulation, and the maximum distance of effective service for either grounded or metallic circuits.

In Brooklyn, the general plan adopted is that of a conduit divided into ducts, through which cables containing from sixty to one hundred wires are drawn. The material of the conduit is for the most part creosoted wood. About ten miles of this is already in use in our city, and about four and a half miles of the Dorsett concrete conduit. For the extensions of the underground systems for the present year, only creosoted timber is to be used.

Among the lessons learned from our experience are: 1st. That in creosoted conduits the use of cables covered with kerite or any similar rubber or gutta percha compound must be avoided. $2 \mathrm{~d}$. That in the so-called lead-covered cables, the use of pure lead is also to be avoided, as it is slowly converted into a porous and friable lead carbonate. 
An alloy of lead, with five or six per cent. of tin seems to resist the destructive action. 3d. That the conducting wire first used is too small for satisfactory telephone service. The difficulties of induction and retardation led to complaints as soon as 4,000 or 5,000 feet of underground wire was put in service. The cables that are now being put in are made up of wires whose cross section is greater by one-third than that of the first wire, and they are protected by twice the thickness of insulation.

I mentioned the above conclusions as having been drawn from our own experience in Brooklyn.

In commencing our work we gathered such information as could be gleaned from localities where solutions of the problem had already been attempted. The impression so largely prevailed that in Europe all telephone and telegraph conductors were underground that our Board decided that a personal inspection of European systems should be made by one of our number. The duty devolved upon me. The result of my inquiry has been published in the scientific papers.

In regard to the burial of the are light wires, I can only say that no method yet tried seems certain of success. Most of them certainly insure the destruction of the underground conductors in from one to three years. But I have no doubt that a solution of the problem will soon be reached. Although the system will be kept apart from the telephone and telegraph subway, it does not scem likely that are light conductors will be allowed in the same conduit with telephone wires, nor will they be distributed from the same man-holes.

In saying that I believe that a solution of the problem will soon be found, I do not mean to assert that casualties like that recently recorded of a man in the Bowery, who lost his life by grasping the naked wire close to an arc lamp, can be prevented by any system of burying wires. To prevent such accidents (if that is the term to be used), the arc lights must be buried with the wires.

All past experience teaches us to proceed cautiously. Nothing can now permanently check the growth of the telephone, the telegraph or the electric light; they have become necessities of our civilization, and any hasty or ill-advised enforcement of the law to convert all aerial to underground systems which should result in serious injury to them, would prove the surest way to perpetuate the nuisance of overhead wires and poies in the streets. 
After reading his paper Professor Plympton proceeded as follows:

The impression that I had received from conversations with people who had seemed to know, was that a large part of the telephone service of Europe was buried in the streets. I was partly disabused of that idea by an engineer who had returned from Europe just as I was setting out. I went to London. I was furnished with letters to various engineers, by engineers and managers of telephone and telegraph companies and civil engineers. I first made the acquaintance of Mr. Preece in London, and learned from him that the Postal Telegraph wires were buried in the streets and that some telephone wires were buried with them-enough for the service of the Post Office Department. A telephone company enjoying franchises in London have run all of their wires overhead, as the manager informed me he could not put a wire underground without an act of Parliament. They bought their right of way over the housetops. There are certainly wires enough in many places there. They do not compare in number and entanglement with ours in New York, simply because there is no such telephone service there, as we are familiar with here, nor is there in any other place. I had submitted the question as to the material of the conduits. He said that after going through a good deal of experience they had adopted iron pipes for their conduits and drew their cables loosely through them. Wires were protected singly, and then two or three, or ten, or a dozen wires were twisted together and pulled through the iron pipe-generally a three inch pipe, rarely larger than four inch. If it was necessary to make connection at some point not contemplated before the pipe was put down they simply knocked a hole in the side of the pipe with a hammer and made the connection. When inquiry was made what they would do in case of so many subscribers along any line of telephone conduit such as we have here in New York, they said that problem was not yet presented to them in London. I examined the system in the streets. These pipes were buried about sixteen or eighteen inches, rarely as much as two feet, ending in little cast iron boxes about twenty inches by sixteen, and perhaps a foot deep, fitted with an iron cover tightly cemented. They sent workmen out, and I was accompanied by Mr. Fleetwood to examine the boxes. They had 
difficulty in raising one or two. I asked why they were so tightly cemented. They said to keep water out. I asked if that was really the effect. They said they thought it was, but the first cover they took off showed me a box with about two inches of water in the bottom. In submitting the question of material for a conduit to Mr. Preece, he answered that iron was used because it would serve better to protect their wires from injury when the streets were dug up by workmen; pick-axes would knock everything else to pieces. He spoke well of our plan of creosoted timber, and took from a case in his office a piece of an old conduit put down in 1853. It had been in the ground thirty-one years. It came out perfectly sound. The cable had given out years ago. It is known that they began systems of telegraphy in Europe by burying all their wires. They tried to bury them along their lines of railway; afterwards dug them up, and now their wires across country are on poles. They are burying in some places in the cities.

I visited Brussels next, and there found a system of arc lighting. Wires were stretched along the street. None were buried. Telephone wires are over the housetops, the wire being in some cases a hard drawn copper wire, in others a silicon bronze. As the houses are high and the house attachments are high, these wires run pretty well up in the air, and as they are small, they do not attract attention as they do here. That is the case generally throughout Europe. They use a small wire and the housetop fixtures are so high that they are not apt to attract attention. A gentleman on the steamer gravely told me that he had been all over Europe and did not see any wires in the air at all ; he knew they were all underground. As the chief manager of the telephone system was in Antwerp, I went on to Antwerp to get information about such telephone service as was under his control. That was Mr. DeGroot. He very kindly offered his time to answer as many questions as I chose to ask. I thought of going on to Stockholm for the reason that I understood the service was very good there, but I learned from Mr. DeGroot that everything was put up under his direction, and with the exception of the frame work on the house-tops everything in Stockholm was duplicated in Antwerp. He thought that no telephone wires in Europe were underground except those that were in the sewers in Paris. He proved to be not quite correct, though pretty nearly so. I asked about his housetop connections. He said 
all through the Belgian and Scandinavian cities the wires were on house-top fixtures. In Italy they were on brackets under the eaves, for the reason that the tiling of the roof does not support very kindly these immense wooden structures. To preserve some degree of coolness in their roofs they put on a triple tiling with little air spaces between the tiles, and it almost destroys the whole roof to put up a wooden structure. Hence, they attach the frame by brackets under the eaves. The style of these you will have an opportunity to see, as I have had these systems extensively photographed in many places in Europe. Mr. DeGroot added that one company had come there with an electric lighting system-and had buried a cable for a short distance, with the intention of lighting the street. It was all buried and they were nearly ready to start, when the gas companies came forward and proved that they alone had the right to dig up the street-the right of canalization of the streets, as he expressed it. The whole plant was lost and now lies buried in the street. He mentioned as an interesting fact that he tried a new plan along the shore of the Scheldt. He had just put up a mile of poles to support his wire. That was a pole line in Europe that they felt rather proud of. I had it photographed and received the photograph since. In Berlin the circumstances are not widely different. There is a series of lines under the municipal direction and some under the direction of the imperial government. There has been a little friction between the two. The first official that I consulted assured me that all telephone wires were on the house-tops; nearly all telegraph wires were buried in the streets and at no great depth, very much like the wires in London, in pipes, not far below the surface. The German military telegraph is of another kind. That is the Siemens cable strongly wound with an armor and buried without any other protection directly in the ground. The telephone wires are very abundant in Berlin over the house-tops. There is quite a tangle of them as you will see by many photographs here. I should add that in Brussels perhaps the most remarkable display of wires anywhere is shown by the photograph, which is a fine picture of their chief cathedral, with wires spread above and running a long distance to their support. In Berlin the house-top fixtures are really very extensive. I never have seen any in New York which were able to carry as many wires at once as those of Berlin. As the government controls the placing of the wires, they are frequently 
placed on their best buildings and some of the very fine views across their favorite avenues show these light iron fixtures on top of public buildings. The difference between the German service and that of Belgium, is that"in Germany the householder must submit to having the fixtures put on his house. $\mathrm{He}$ is paid, however, for the service. In Belgium they make the best terms they can, and the telephone companies pay at about the rate of ten cents per wire per year for the use of the house-top.

One picture represents the central station in Turin where there is a great assemblage of wires coming over the house-tops. In Brussels one difficulty which Mr. DeGroot said he had experienced was from the disturbance of the wires by angry citizens. The wires were so thick that they killed a great many carrier pigeons. Owners of pigeons would get angry and go up on the house-tıps and cut down the wires. Fifty wires were destroyed the day before. An old lady who owned a number of pigeons had cut them.

Cologne has, I think, about five hundred telephones-it was August, 1886, that I was there--and Frankfort about four hundred. Four, five or six hundred is about the number for the cities in central Europe.

In Paris a different condition prevailed. I went directly to the electrician. I had letters from Mr. Edison and Mr. Vail introducing me to M. Berthon, in whose charge are all the telephone lines of France. I asked him immediately about his underground system in the sewers. He said, "Yes, they are in the sewers, but they are there because the sewers are right at hand." I asked him, "What do you do when you come to the end of your sewers?" He said, "Then we come out and go to the housetops." A little later he showed me a wire drawn out of a sewerdrawn right up, fastened to the side and drawn up to the house where it is wanted. I asked him what was the plan in other French cities. He said they were all on the house-tops except in Bordeaux, where about three hundred subscribers are furnished by a system drawn through iron pipes, but the system is not doing very well. I visited the sewers and walked along through them some distance. I noticed the method of attaching. It was a little hook with a shank, driven into the wall over head; I could just reach it with my hand. That would hold four or five cables each as large as my thumb. There would be twelve or fourteen of those small cables in a single one of these sewers. It was easy to make out the distance of these cables as they branched off, be- 
cause the sewers are very conveniently marked; the street corners are marked with the name of the streets. In regard to the are lighting, I asked him if he would put the arc light wires in the same sewers with his telephone wires, and he said "No," very energetically - he would not have them there; indeed, he did not believe that are lighting was going to prevail to any great extent, and then added, "We have less now in this avenue that you are in (Avenue de l'Opera) than we had three or four years ago; we have replaced the arc lights with the gas lights." The gas lights are in groups, five or six burners in each lamp. There were no arc light wires underground, so far as he knew. I noticed while walking with him along the street that there were some wires overhead. He said those were some of the dead wires not yet removed; but he called the superintendent, who was in sight, and submitted the question to him. The superintendent said no, that the wires were overhead, as there was no sewer in that street; it was a short street. Then M. Berthon added, "There are one hundred subscribers served that way," and again the superintendent interposed to say that there were two hundred in Paris served over house-tops solely. M. Berthon added that in regard to the telephone service that he expected to be able to extend it through Spanish cities; it was a franchise that he was expecting to control very soon, but he had made it a condition that he should be allowed to go on house-tops. So I got but little information with regard to the best way of burying wires until I got back to England, when, after a short stay and another consultation with the electricians there, I went on to Newcastle. I was assured that they were beginning to put wires underground in Manchester. If I went there I should see that they were burying a cable in an iron pipe. Newcastle enjoys the reputation of having all its wires underground. They have a system of iron pipes. They serve some three hundred or four hundred telephone subscribers by the use of the wires controlled by the Government. They do not study economy in the method of hauling in wires or in the use of them. They twist their wires together so as to to establish a metallic circuit and run from their central station to their customers.

I had got this estimate from both M. Berthon and Mr. Preece:that when the underground system was fully at work with cables, the best that they knew how to make, the limit of service would be about ten or eleven miles underground. I asked if it would 
be profitable to run further than that if the conductors came out of the ground at that distance. They said that was doubtful; it was a question not solved. M. Berthon gave twelve miles as about the limit which it was possible to send a telephone message through anything buried in the ground. I mentioned that to the electrician who was assigned to me by Mr. Heaviside, the head of the telephone service in Newcastle, and he said, "I cannot quite accept that estimate, and I think I will give you an opportunity to refute it." So he connected up a line for me to experiment with, which he said was a line of twelve and a half miles of cable-what he called cable, that is, a lot of wires twisted together in pairs, twisted a little way in one direction and then twisted in the opposite direction. These pairs were put together until there would be about a dozen or twenty and then they were pulled loosely through the iron pipe. At the end of the twelve and a half miles the wire came out of the ground and connected for about thirty-eight miles further. It was fifty miles and a fraction through which he said the telephone service extended. I could converse through that, though I found difficulty, where an expert worker at the telephone would not. I could converse through that when the conditions were exceptionally favorable. It was in a padded room and the instrument was in perfect working condition. I had no difficulty in conversing through that twelve and a half miles of cable and the aerial line up to fifty miles. Such telephone service as they have in Newcastle would hardly answer the purpose where there are so many users as we have here. I asked how they increased the number if they had any additional subscribers-how could they pull more wires into the iron pipe that had a twisted tangle of wires already in it. He said they pulled the whole bundle out and sent them to headquarter's-the Postal Departmentand they furnished them a new lot. Economy was not considered. He said the Government owned the whole thing.

DISCUSSION.

Mr. J. A. Powers: As a central station operator, I should be glad to ask if there are any are light wires buried underground; what is the longest time for which such wires have been buried up to the present time?

Prof. Plympton: I cannot tell that. We have had no expe- 
rience of that kind in Brooklyn. The are light company appears to be ready to try experiments when they see their way clearly. We have been more interested in getting the telephone wires underground, because they outnumber all the others.

Mr. Powers: There seems to be in this matter a very grave misunderstanding by the public about the danger of the electric light wires themselves. I have kept a close track of this subject since there has been some agitation of this underground question at Troy. I have also kept close track of the accidents recently, and I have noticed that four out of five do not occur from the electric light wires directly, but from the coming down on the electric wires of, I think, principally, abandoned wires overhead. The nuisance has become so great in Troy that a law was recently passed by the Common Council requiring the city engineer to remove those wires, and there is now a mutual action of the telephone, telegraph and electric light companies to see to the removal of those wires. We had one accident a short time since. An abandoned Atlantic and Pacific telegraph wire fell down across ours and killed a horse, through no prime fault of the electric light company. If we can get the telegraph and telephone wires underground, which seems to be possible, we shall have, if the recent accidents are any criterion by which to judge, fourfifths of the danger removed at once, and I think that the question of danger will then sink into comparative insignificance.

Mr. C. O. Marlloux: I would like to ask Prof. Plympton if he has any data regarding the working of the underground system at Chicago. I believe the underground system has been working there on a considerable scale. It might be interesting for him to tell us whether he has any personal knowledge regarding it. His treatment of the underground systems in Europe is certainly a very masterly, and thorough and comprehensive one, and there is but very little for us to say either by way of comment or otherwise. But it is quite evident to the minds of us all, that they have not done anything in Europe that we can safely and conscientiously recommend for our own particular cases, because not only are the systems more numerous in this country, but they are also exploited on a much larger scale, so that a remedy which might be adequate in Europe would not be adequate here, and for that redson I would like to know what Prof. Plympton may have learned of systems which are promising success in this country. 
Prof. Plympton:-I visited Chicago and was very politely received by Mr. Barrett, who is superintendent of the work there. He said that he began by forming an agreement with various companies that they should bury their wires as fast as he buried the wires of the city. He is City Electrician. He allowed the companies to select their own conduits, so that each company has its own. They have telephone wires, telegraph wires and underground electric light wires for some purposes. There is no municipal street lighting in Chicago, or was not a year ago last February. Some theatres and buildings are lighted, but the wires run through conduits. That was the case where one of the conduits took fire. I wrote to Mr. Fay and asked about the telephone service, to learn if they had suffered from induction owing to proximity to any of these other wires. They had in some cases. The harmonic system of telegraphy had created some difficulty through its induction, and there had been complaints, but inasmuch as each company had selected its own conduit, and buried its wires in its own way, there was not much to gather about a general system of burying, of getting them into as compact shape as could be done. Indeed, standing at one of the street corners one of the electricians pointed out to me fifteen man-hole covers in sight at the junction of two streets, all within a radius of less than sixty feet. They have there a short way of making connection. Their soil is soft, light sand. They take a sharp-pointed pipe and drive that pipe right across the street, if they want to make a house connection. It may turn out in the middle of the track, and then they pull the pipe out and start again.

In regard to getting information from other sources, the remark made by Mr. Parrish in London was significant. He said: "If I had been asked about the best place to go to learn about underground systems, I should have said the United States. We have none here." I found that to be the case. They can come here to learn about underground systems. They cannot overtake our rapid development.

The Chairman: Unless there are some other remarks we will pass to the consideration of the next paper-_" The Patent Court and Uniformity in Patent Practice," by Mr. George H. Stockbridge.

Mr. Stockbridge: You will remember that some time ago Mr. Steuart, representing the National Electric Light Association, read a paper before you, in which he pointed out certain 
reforms that were regarded as necessary by that association, and there was, I believe, a discussion here of the reforms that were pointed out at that time. I believe it was the design of the association to present bills to Congress embodying the reforms suggested by Mr. Steuart, and embodying them in a revision of the Patent law. That scheme, however, met with opposition from some, and instead of that, two bills were presented by the association to Congress, and one of them provides that a patent court be established to have appellate jurisdiction from the Commissioner of Patents in all rejected cases, and the other is that the Commissioner of Patents receive a salary of $\$ 8,000$. Mr. Steuart asked me to prepare an argument to be submitted to the Judiciary Committee, before whom the bill on the patent court now is, and I prepared such an argument, taking rather a narrow point of view, so as not to interfere with different arguments that were to be made by the other parties.

Mr. Stockbridge then read the following paper. 